\title{
Management of peri-implantitis associated with tear-like implant fracture: case reports
}

\author{
Yeon-Tae Kim, Jae-Hong Lee ${ }^{1,2}$, Seong-Nyum Jeong ${ }^{1,2 *}$ \\ 'Department of Periodontology, Daejeon Dental Hospital, Wonkwang University College of Dentistry, Daejeon, Republic of Korea \\ 'Institute of Wonkwang Dental Research, Wonkwang University College of Dentistry, iksan, Republic of Korea
}

Implant fracture is rare, but one of the most serious problem in implantation. Treatment of implant fracture can be different according to the extent of the fracture and on the state of the surrounding prosthetic restoration. Maintaining or submerging implant after treatment of peri-implantitis can be useful options for cases of tear-like fracture on the coronal area of an implant. (J Dent Rehabil Appl Sci 2020;36(2):138-44)

Key words: dental implants; fractures; peri-implantitis

\section{Introduction}

Cases of implant-related complications have increased in proportion to the widespread use of implants. Moreover, patients receiving treatment for peri-implantitis and maintenance treatment are becoming common. The survival and success rates of implants have been reported to be as high as 90 to $95 \%$, and are increasing gradually. However, various types of failures and adverse effects are observed with use of implant, among which, one of the most serious complication is implant fracture.

In the study by Balshi, ${ }^{1}$ the frequency of implant fracture was $0.2 \%$ of the 4045 patients with implants, and that in the study by Eckert et al. ${ }^{2}$ was $0.5 \%$ of the 4,937 patients with implant. In addition, many previous studies have reported rare occurrence of implant fractures (0.18 to 5\%); however, the occurrence of fracture becomes a critical problem to both

*Correspondence to: Seong-Nyum Jeong

Professor, Department of Periodontology, Daejeon Dental Hospital, Wonkwang University College of Dentistry, 77 Dunsan-ro, Seo-gu, Daejeon, 35233, Republic of Korea

Tel: +82-42-366-1114, Fax: +82-42-366-1115, E-mail: seongnyum@wonkwang.ac.kr Received: March 17, 2020/Last Revision: May 4, 2020/Accepted: May 21, 2020 the patient and surgeon. ${ }^{3-5}$ Implant fractures can be caused by a combination of various biological, mechanical, and technical factors, including (1) patientrelated factors, such as the parafunctional activity and plaque-induced peri-implantitis; (2) prosthetic factors, such as inadequate prosthesis design or occlusion; (3) implant factors, such as the structural weakness of specific design of implants, and (4) overloading resulting from the peri-implantitis-induced marginal and vertical bone loss. ${ }^{6-9}$

Generally, three methods for treating cases of implant fracture include (1) replacing the fractured implant with another; (2) performing a prosthetic restoration after submerging the fractured implant; (3) repairing the fractured implant and replacing it with a prosthetic appliance. ${ }^{1}$ This study describes the cases of treatment of tear-like fractured implant with the treatment of peri-implantitis, while preserving the implant. 


\section{Case Report}

\section{Case 1}

In November 2017, a 46-year-old male with no medical history visited the hospital because of the implant mobility at the right mandible. This patient had implant installation at the first and second molar positions on the right mandible (\#46, 47) in May 2013. After the prosthetic restoration in December 2013 (Fig. 1A), regular implant maintenance has been performed. As of July 2017, no major clinical symptom, such as bone loss, was observed on periapical view (Fig. 1B); however, in November 2017, upper prosthesis mobility and a circumferential bone loss around the \#46i were observed on the periapical view (Fig. 1C). On the day of this observation, the prosthodontist performed re-tightening of the implanted screw, and periodontist scheduled a surgery for treating the peri-implantitis. On buccal flap elevation, the implant thread was exposed; the fracture line was observed in the mesial and buccal sides of the implant fixture (Fig. 2A). The fragment size was $2 \times 3 \mathrm{~mm}$ (Fig. 2B). After carefully removing the fragment, chemical decontamination and mechanical debridement using an air abrasive device, tetracycline (TC) cotton, and TC irrigation were performed to treat the peri-implantitis. Around the intra-bony defect area, xenobone grafting, application of enamel matrix derivates (EMD), and Biotex ${ }^{\circledR}$ (Purgo, Seongnam, South Korea) suturing were performed. On subsequent visit for follow up after 3 and 15 months, no bleeding on probing (BOP) or pus discharge were observed on clinical examination (Fig. 3A). On the periapical view, the defect was found to have recovered without observations of any abnormality statement (Fig. 3B, 3C).
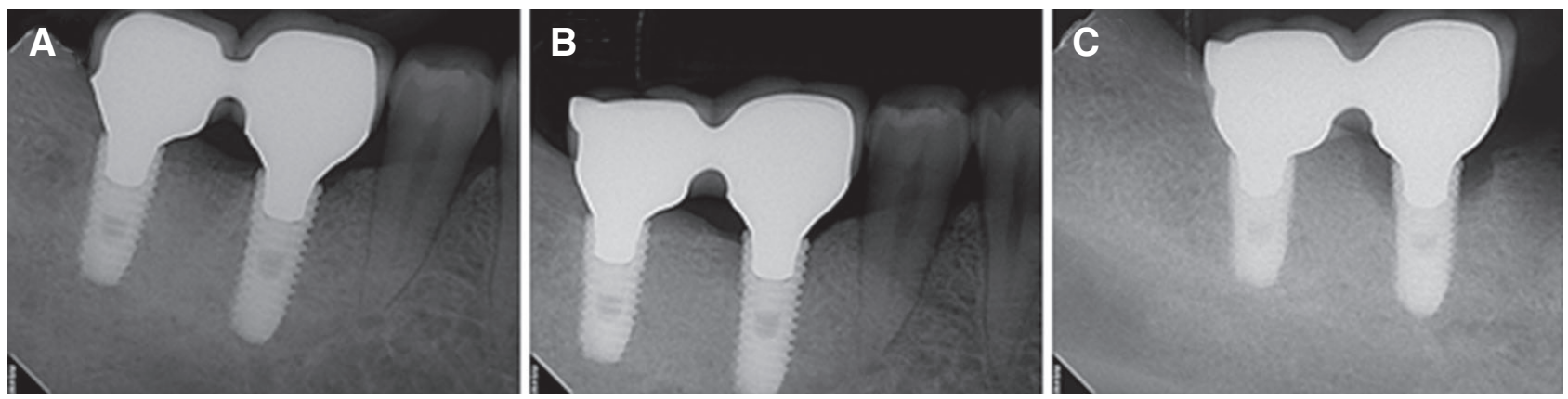

Fig. 1. Periapical radiography of case 1. (A) Prosthesis delivery on December 2013. (B) There are no major clinical symptoms detected at 4-years follow up. (C) Rapid and aggressive peri-implant bone loss on the \#46 implant occurred with prosthesis agitation 4 month after last follow up.
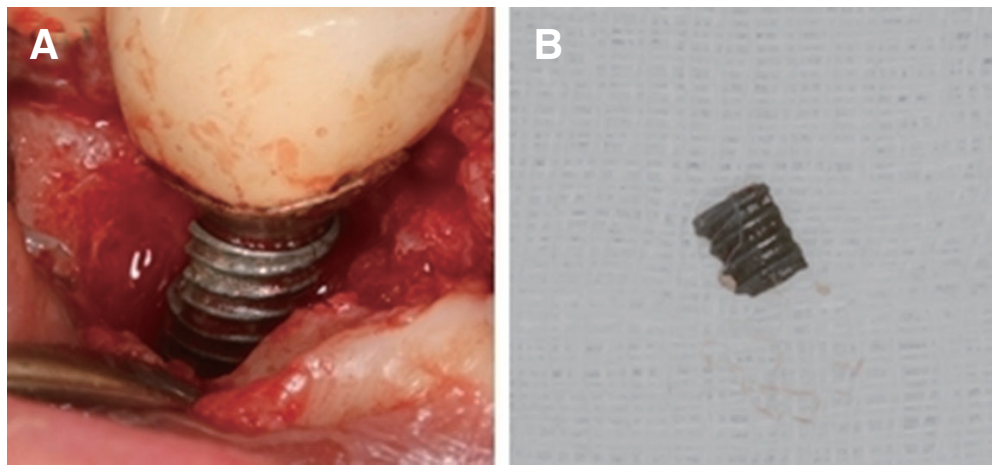

Fig. 2. (A) Intraoral photograph of peri-implnatitis surgery of case 1: Peri-implant bone loss with buccal and mesial implant fracture lines were observed. After removing the fragment and surface decontamination, xenobone grafting combination with enamel matrix derivates were performed around the defect area. (B) Removed fractured fragement. Fragment size: $2 \times 3 \mathrm{~mm}$. 

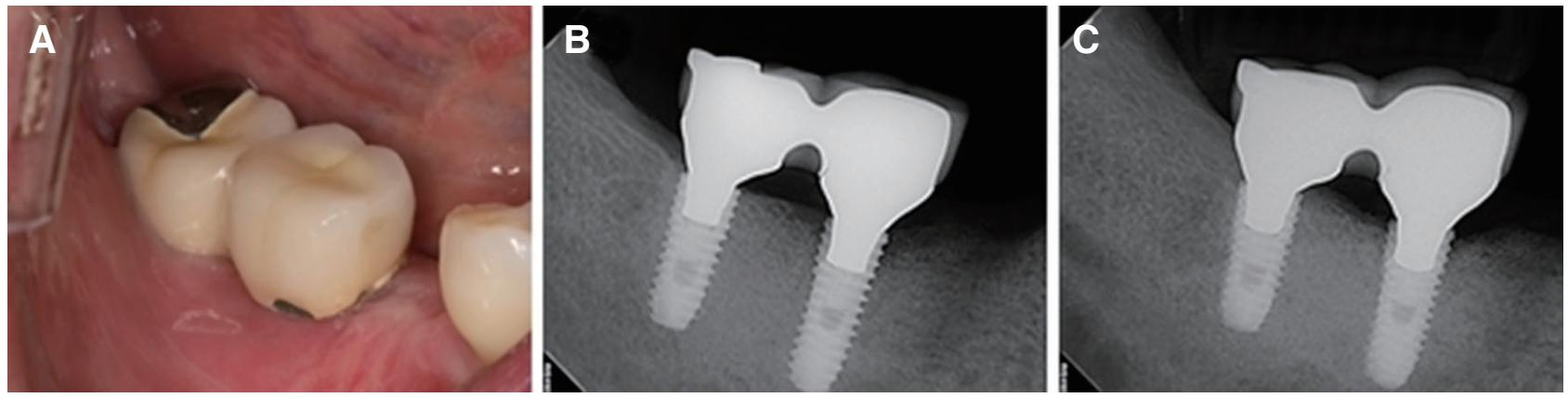

Fig. 3. (A) Intraoral photograph of case 1: no specific sign at 3 month follow up. (B) Periapical radiography: 3 month follow up after peri-implantitis surgery with indicating defect fill. (C) On 15 month follow up periapical radiography, surgical site is maintained stable without any abnormal sign.

\section{Case 2}

A 69-year-old man with no medical history was diagnosed with peri-implantitis at the premolar part of the left mandible. Approximately 5 years ago, he underwent an implant placement at the local clinic on teeth \#35, 36, and 37, which were then restored with a splinted crown. A $6 \mathrm{~mm}$ probing pocket depth was observed at the buccal side of \#35, and a circumferential bone loss was observed in the periapical view (Fig. 4). Additionally, on clinical examination, BOP and pus discharge were observed; however, no implant mobility or discomfort in mastication were reported. On flap elevation, the fracture lines were observed in the mesiobuccal and distobuccal sides (Fig. $5 \mathrm{~A})$. The fractured fragment was removed carefully (Fig. 5B). The fragment size was $1.5 \times 3 \mathrm{~mm}$. Similar

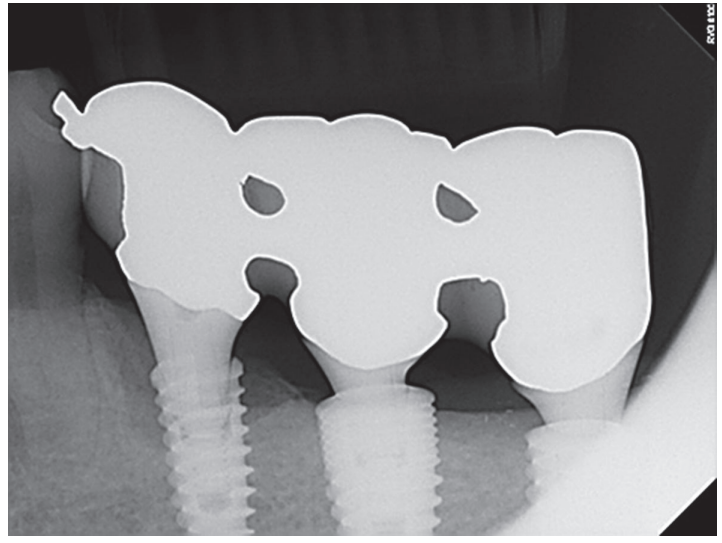

Fig. 4. Periapical radiography of case 2: Periimplant bone loss on the \#35 implant was detected approximately 5 years after implantation.
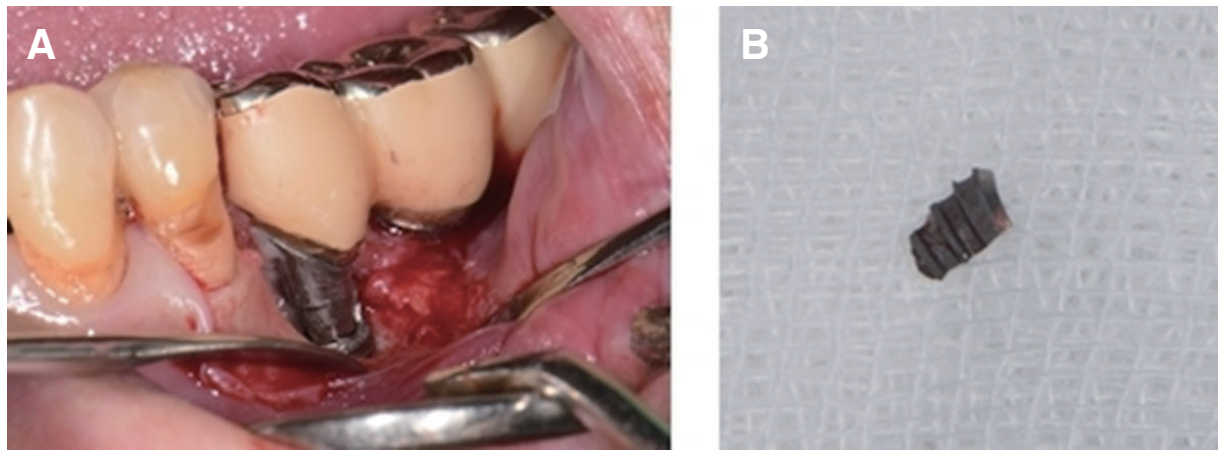

Fig. 5. (A) Intraoral photograph of peri-implnatitis surgery of case 2: Buccal bone loss and buccal implant fractures were observed. After removing the fragment, mechanical debridement and chemical decontamination were performed. (B) Removed fractured fragement. Fragement size: $1.5 \times 3 \mathrm{~mm}$. 


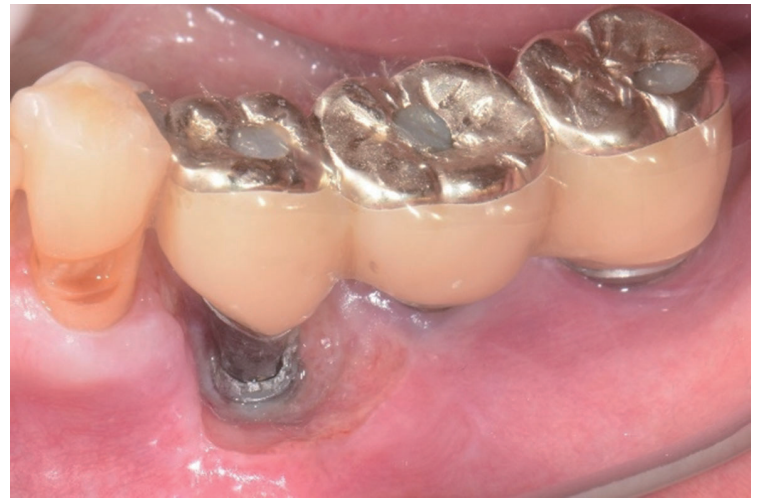

Fig. 6. Intraoral photograph of case 2: 2 weeks after periimplantitis surgery, healing with buccal fractured line is exposed. After surgery, the implant functioned stably for 5 months.

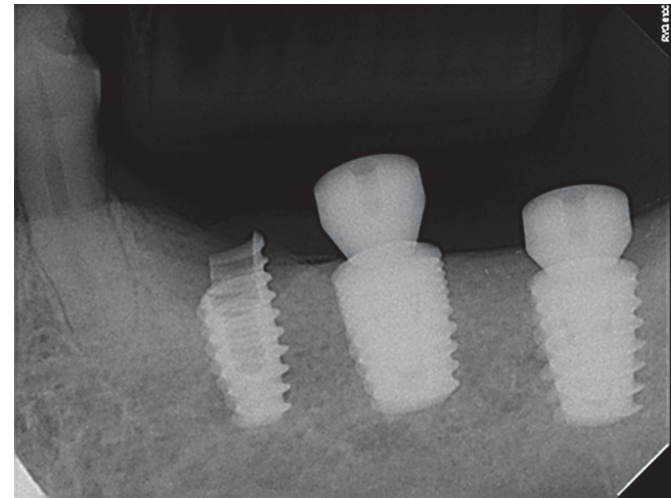

Fig. 7. Periapical radiography of case 2 : A radiograph with a healing abutment on \#36, 37 implants to fix the prosthesis. 5 months after peri-implantitis surgery, due to fractured part, mobility and retention loss of restoration occurred. It was planned to remain submerged a \#35 implant and removed it later if necessary.

The direction of biting force and the crownimplant ratio are major factors determining implant fracture. de Moraes et al., ${ }^{11}$ using 3-dimensional analysis, examined the level of stress on dental implants depending on the direction of implant load. When the force was applied to non-axis direction, excessive pressure was applied to the upper part of an implant fixture as compared to that when the force was applied in the right direction. As per published reports, even at the same angle, as crown-implant ratio increased, the extent of stress increased further. Shinogaya et al. ${ }^{12}$ stated that the frequency of periimplantitis and implant fracture was higher for men than women because of the stronger biting force in men. As mentioned earlier, application of a strong biting force in the improper direction or the use of biting force that exceeds the resistance of the restoration increases the risk of fracture.

To detect such cases of implant fractures in clinical settings, the frequency of occurrence of screw loosening, peri-implantitis, sudden radiological bone loss, or manifestation of fracture line need to be clinically assessed. $^{10,13}$ It was reported that frequent loosening of an implanted screw, fracture, or bone loss around the implant will likely result in implant fracture. ${ }^{1,14}$ The implant fracture lines may involve a rapid and 
aggressive bone loss around the implant, which can result in implant fracture or result from fracture. ${ }^{14,15}$ In the first case examined in this study, sudden radiological bone loss was observed along with screw loosening. In the second case, there was no presentation of implant mobility related to the splinted crown, but there was a sudden radiological bone loss along with any clinical symptoms such as pus discharge. Various factors may contribute to implant fracture, and only one or all of the abovementioned symptoms might have been observed in patients. The presence of these symptoms is indication of a probability of implant fracture.

In cases of implant fracture, attention must be paid to the extent of the fracture and on the state of the surrounding prosthetic restoration. As shown in the two cases here, when dealing with tear-like fracture of the coronal area of an implant, the treatment for peri-implantitis treatment must be performed first, and subsequently, maintenance treatment, as described in Case 1, need to be performed conditionally depending on the extent of fracture and with the possibility of maintenance of the upper part of the prosthesis. Moreover, implant submerging or implant removal can be considered as described in Case 2 . Implant removal and replacement can also be an option, but the difficulty associated with path reformation, need for re-operation, and financial burden must be taken into consideration. Therefore, for cases of tear-like fracture of the coronal area of an implant, the treatment for peri-implantitis, implant maintenance, or allowed to remain submerged can be considered as useful options.

\section{Conclusion}

For cases of tear-like fracture on the coronal area of implant, clinician may consider maintaining or submerging the implant after peri-implantitis surgery instead of explantation.

\section{Acknowledgements}

This study was supported by Wonkwang University in 2020 .

\section{ORCID}

Yeon-Tae Kim https://orcid.org/0000-0001-7209-3208

Jae-Hong Lee https://orcid.org/0000-0002-2375-0141

Seoung-Nyum Jeong https://orcid.org/0000-0003-4890989X

\section{References}

1. Balshi TJ. An analysis and management of fractured implants: a clinical report. Int J Oral Maxillofac Implants 1996;11:660-6.

2. Eckert SE, Meraw SJ, Cal E, Ow RK. Analysis of incidence and associated factors with fractured implants: a retrospective study. Int J Oral Maxillofac Implants 2000;15:662-7.

3. Goodacre C, Goodacre B. Fixed vs removable complete arch implant prostheses: a literature review of prosthodontic outcomes. Eur J Oral Implantol 2017;10 Suppl 1:13-34.

4. Jung RE, Pjetursson BE, Glauser R, Zembic A, Zwahlen M, Lang NP. A systematic review of the 5 -year survival and complication rates of implantsupported single crowns. Clin Oral Implants Res 2008;19:119-30.

5. Adell R, Lekholm U, Rockler B, Brånemark PI. A 15-year study of osseointegrated implants in the treatment of the edentulous jaw. Int J Oral Surg 1981;10:387-416.

6. Mendonca G, Mendonca DBS, Fernandes-Neto AJ, Neves FD. Management of fractured dental implants: a case report. Implant Dent 2009;18:10-6.

7. Stacchi C, Berton F, Perinetti G, Frassetto A, Lombardi T, Khoury A, Andolsek F, Di Lenarda R. Risk factors for peri-implantitis: Effect of history of periodontal disease and smoking habits. A systematic review and meta-analysis. J Oral Maxillofac Res 2016;7:e3.

8. Roccuzzo M, Bonino L, Dalmasso P, Aglietta M. Long-term results of a three arms prospective cohort study on implants in periodontally compromised patients: 10-year data around sandblasted and acid-etched (SLA) surface. Clin Oral Implants Res 2014;25:1105-12.

9. Roos-Jansåker AM, Lindahl C, Renvert H, Renvert 
S. Nine- to fourteen-year follow-up of implant treatment. Part I: implant loss and associations to various factors. J Clin Periodontol 2006;33:283-9.

10. Tagger-Green N, Horwitz J, Machtei EE, Peled M. Implant fracture: a complication of treatment with dental implants-review of the literature. Refuat Hapeh Vehashinayim 2002;19:19-24, 68.

11. de Moraes SLD, Verri FR, Santiago JF Jr, de Faria Almeida DA, de Mello CC, Pellizzer EP. A 3-D finite element study of the influence of crown-implant ratio on stress distribution. Braz Dent J 2013;24:63541.

12. Shinogaya T, Bakke M, Thomsen CE, Vilmann A, Sodeyama A, Matsumoto M. Effects of ethnicity, gender and age on clenching force and load distribution. Clin Oral Investig 2001;5:63-8.

13. Proceedings of the 4th International Symposium on Implant Dentistry: Focus on Esthetics. San Diego, California, January 27-29, 1994. Abstracts. J Prosthet Dent 1994;72:623-34.

14. Misch CE, Suzuki JB, Misch-Dietsh FM, Bidez MW. A positive correlation between occlusal trauma and peri-implant bone loss: literature support. Implant Dent 2005;14:108-16.

15. Sánchez-Pérez A, Moya-Villaescusa MJ, JornetGarcia A, Gomez S. Etiology, risk factors and management of implant fractures. Med Oral Patol Oral Cir Bucal 2010;15:e504-8. 


\section{열리형 임플란트 파절과 연관된 임플란트 주위염의 관리: 증례 보고}

\section{김연태 ${ }^{1}$ 전임의, 이재홍 ${ }^{1,2}$ 교수, 정성념 ${ }^{1,2 *}$ 교수}

${ }^{1}$ 원광대학교 치과대학 대전치과병원 치주과

${ }^{2}$ 원광대학교 치의학 연구소

임플란트 파절은 드물게 발생하나, 임플란트와 관련된 가장 심각한 부작용 중 하나이다. 임플란트 파절에 대한 처치법은 파절의 정도와 이와 관련된 보철 수복의 상태에 따라 달라질 수 있다. 임플란트 주위염 처치 후, 임플란트를 유지하거나 혹은 묻어두는 방법은 치관측에 발생한 열리형 임플란트 파절 증례에서 유용한 선택이 될 수 있다.

(구강회복응용과학지 2020;36(2): 138-44)

주요어: 치과 임플란트; 파절; 임플란트 주위염 